Cristina-Elena GOGÂŢĂ

Faculty of Medicine, "Iuliu Hațieganu” University of Medicine and Pharmacy

Cluj-Napoca, Romania

cgogata@yahoo.com

\title{
WHEN CENSORSHIP IS OVER - ANA BLANDIANA'S RETURN TO WRITING AFTER THE 1989 REVOLUTION
}

Recommended Citation: Gogâță, Cristina-Elena. "When Censorship is over - Ana Blandiana's Return to Writing after the 1989 Revolution." Metacritic Journal for Comparative Studies and Theory 5.1 (2019): https://doi.org/10.24193/mjcst.2019.7.05

\begin{abstract}
This paper aims at retracing Ana Blandiana's ban from publishing, between 1988 and 1989; it also looks at the way in which the writer managed to elude censorship. Ana Blandiana was banned from publishing during the one and a half year before the end of the communist regime in Romania. The reviews of her last poetry anthology were banned, but not the anthology itself, which was published shortly after the author's ban from publishing. Ana Blandiana's name was allowed to appear in literary studies about generations and groups of poets, but book reviews regarding her literary works were not allowed. The writer lost her column in the literary magazine "Familia," but kept writing another column, anonymously, in the same magazine. Our study looks into the fresh memories of literary critics and Ana Blandiana's confessions, in the days following the events of 1989, in order to explain a paradoxical case of censorship: banning discourses about a writer, but allowing the author's discourses.
\end{abstract}

Keywords: communism, Ana Blandiana, censorship, Familia, Poezii, subversive literature

Recent critical and theoretical discourses about Romanian literature in communism emphasize the complex nature of the Writer-Power relationship, which means that literature, too, is analyzed and assessed from extra-aesthetic standpoints. Ion Simut addresses the existence of four literatures in this period, based on the writers' approach to the politicization of the literary discourse: opportunistic, dissident, 
escapist, and subversive (Simuț, Literaturile 12). While opportunistic literature can be identified with ease, and escapist literature is read as a "passive solution of the writer giving the cold shoulder to investment in reality" (Simuţ, Literaturile 360), the differences are subtler in the other two categories. As pointed out by the author himself, there is a difference in rank between subversive literature and dissident literature (Simuţ, Literaturile 383), which makes it difficult to assess at which point subversive literature becomes dissident - and not the author himself/herself. The former needs to meet the following requirements: the text has to be published in the country, before 1989, it should have elicited a reaction from the readers and the officials' post-editorial response (Simuț, Literaturile 49). From this point of view, the historian criticizes the overbidding of subversion by the young researchers (Simuț, Literaturile 63), considering that many of the analyzed texts would not have led to the officials' post-editorial reaction.

Nevertheless, when we look at factors such as pre-editorial control, the writers' self-censorship (Macrea-Toma 232) or the readers' response to the literary product, things get complicated and the borders separating the escapist, subversive and dissident literatures soften. Liviu Malița examines the writers' relationship with Power from the viewpoint of Censorship and of the State Security. Like Ion Simuț, the researcher presses the point of the complex nature of the literary phenomenon and of the impossible Manicheism between the writer and Censorship: temporary alliances between censors and writers, writers occupying public offices that censors find intimidating, editors considered propagandists, but who undermine the system from within, the "liberating" actions of some party activists, to avoid a potential scandal, all these examples, not in the slightest singular ones, illustrate the Brownian nature of the literary process in communist Romania (Malița, Cenzura 16-18). Such an undertaking proves the existence of texts written with a subversive intent, but which pass Censorship effectively, owing to interventions like the aforesaid ones, precisely because the communist Power, especially in the ninth decade, avoids the practice of the ban, given the value-raising potential it has for the writer (Malița, Cenzura 337). Particularly in the 1980s, after the formal ending of Censorship as an institution and, implicitly, by the growth of the State Security's role in the supervision and moderation of writers, we can see the increasingly higher recurrence of "the economy of suspended rights" (Foucault 16) in the Romanian literary sector. On the other hand, it is precisely this formal dissolution of censorship that leads to its chaotic 
multiplication, in the obsessive attempt to control everything, while its prolix character allows omissions, errors or abuses (Malița, Cenzura 334-8).

Therefore, considering literature's polysemic characteristics, as well as the ambiguous relationships among the players of the literary sector - writers, publishers, editors, censors, representatives and informers of the State Security - this analysis seeks to retrace the history of the publication and reception of the last volume published in the communist period by Ana Blandiana, a female writer who was banned at the time when the volume appeared; we also try to circumscribe the phenomenon under which the same Ana Blandiana, banned writer, continued to publish anonymously, under the wary eye of the Censorship and of the State Security.

On December $28^{\text {th }} 1989$, during the first days of a recovered freedom of speech, the first censorship-free issue of the magazine România literară is published. On page 23 - former page of the "Atlas" column - Ana Blandiana's "Cruciada copiilor" ("Children's Crusade") is printed, a symbolic text both owing to the title that evokes the poems in Amfiteatru and owing to the position occupied in the magazine. Unlike the homonymous poem, the tablet brings up the twofold status of those who took part in the revolution: bound to be born under the decree 770/1966 and invested with the aura of the communist superlative - by the use of all the clichés attached to the official discourse specific to the communist "golden age" - it was precisely this generation that rose against the oppressive regime and contributed to the start of the events of 1989. The text with which Ana Blandiana makes her return to the public space is dedicated to the heroes of the revolution:

I would like that the first words written on this page corner, to which I return as if I returned within myself, be a hymn for them, for the young who are dead and the young who are alive and who achieved the miracle of this deed able to lift us from the frozen undergrounds of the century to its burning peaks. The events of these days and of the years and decades to come are and will be the work of children born by mothers in despair over the fact that they had to give birth to them, children raised in silence, in fear, in cold and in hunger, children watched over by parents terrorized by denunciations and exhausted by waiting in queues, children educated by teachers humiliated and pushed into duplicity, children taught to speak softly, to have their radio volume down, to cover the phone, to be wary of one another, not to trust anyone, not to believe in anything. All our experiences now are the actions of these children sentenced to birth and to solitude, who, scornful of the guilt that had been enforced 
upon them, threw it at the pitiless meters of history, using it to pay for solidarity and love, for faith and hope and who made us all be born in this blood-stained and sublime Christmas. May the miraculous crusade of Romania's children manage to keep unchanged the freedom bought for such a high price and guide it through the years, as pristine and as brilliant, filled with the maturity of irreversible democracy ${ }^{1}$ (Blandiana, "Cruciada" 23).

A first observation regarding the above-quoted text relates to how the release of speech from censorship is likened to a return within oneself, with the replenishment of the being by the use of writing. The un-censoring of the self can also be seen among the literary critics, since the pages of the same issue of the magazine also host Nicolae Manolescu's review of the edition of Poezii (Poems) by Ana Blandiana, of 1989. As confessed by the author of the review, in a Preamble, the text had been censored, despite all the precautions that were taken. Nicolae Manolescu remembers that his article was removed from the ninth page of România literară, without any explanation communicated to the editorial staff. When the critic called the person in charge of România literară at the Council of Culture, he was told that the issue "transcended" him. Only later did the critic find out a possible reason for the banning of his text:

One of the security officers who interrogated Dan Deşliu (another banned poet that year) told him (and the poet told me) that I "made bad blood" (the jargon!) in the article. I only acknowledge one thing. You can find it in the last sentence, where I write I cannot dare to predict anything about Ana Blandiana's poetry - "about hers less than about anyone else's". And how could I have dared? The text published today is exactly the same delivered to the magazine six months ago² (Manolescu 9).

${ }_{1}$ "Vreau ca primele cuvinte scrise în acest colț de pagină, unde mă întorc cum m-aș întoarce în mine însămi, să fie un imn închinat lor, tinerilor morți și tinerilor vii care au produs miracolul acestei fapte în stare să ne înalțe din subteranele înghețate ale veacului pe culmile lui care ard. Ceea ce trăim azi și ceea ce vom trăi în anii și în deceniile următoare este și va fi opera acestor copii născuți de mame disperate că trebuie să-i nască, crescuți în tăcere, în frică, în frig și în foame, îngrijiți de părinți terorizați de denunțuri și epuizați de statul la cozi, educați de învățători umiliți și obligați la duplicitate, învățați să vorbească în șoaptă, să pună radioul încet, să acopere telefonul, să se ferească unii de alții, să nu se încreadă în nimeni, să nu creadă în nimic. Tot ce trăim este fapta acestor copii condamnați la naştere și singurătate, care cu un uriaş dispreț pentru vina care li se dăduse cu sila au aruncat-o pe contoarele nemiloase ale istoriei, plătind cu ea solidaritatea și iubirea, credința și speranța și ne-au făcut să ne naștem cu toții în acest Crăciun însângerat și sublim. Fie ca miraculoasa cruciadă a copiilor României să păstreze neschimbată libertatea cumpărată atât de scump și să o ducă prin ani, la fel de curată și de strălucitoare, plină de maturitatea ireversibilei democrații” (My translation).

2 "Unul din ofițerii de securitate care l-a interogat pe Dan Deșliu (alt poet interzis al anului) i-a spus (și poetul mi-a spus mie) că «băgam fitile» (jargonul!) în articol. Recunosc unul singur. îl puteți 
The reasons why the Power chose to publish Ana Blandiana's anthology of Poezii in 1989 continue to be unclear. Liviu Malița offers a potential explanation, as the complete banning of an author would have had the undesired effect of increasing his or her notoriety:

...while the writers' expressive resistance, by their work, only rarely experienced high points, Censorship, in its turn, avoided, as much as possible, radical actions and forceful measures. The total bans on the publishing of a manuscript belonged to the regime of expression. Currently, the Censorship's apparently mollifying attitude was explained by the Power's fear of scandal, but also by a correct instinct of the censors who stood away from creating, like Inquisition once did, martyrs, exemplary figures, by investing them with notoriety3 (Malița, Literatura 330).

It is certain, however, that Ana Blandiana was a writer banned from August 1988 to the fall of communism, and so were the reviews of the anthology. Nicolae Manolescu's case is not singular, because, in the first issue of 1990 of the magazine Tomis, Vladimir Bălănică recounts a similar experience: the critic remembers that his article was also rejected without explanation, which led him to interpret the publishing of the anthology as a strategy of appeasement:

The "Center" did not allow it, just like it did not allow many other things. The whole state of things was inconceivable: so, you could not write about a book printed and disseminated in 1989?! Its publication was, it seems, a propagandistic act of "good will”, to “appease the spirits” or I don’t know what other obscure reasons4 (Bălănică 8).

găsi în ultima frază, acolo unde scriu că nu mă încumet să pronostichez nimic în legătură cu poezia Anei Blandiana - «cu a ei mai puțin decât cu a oricui». Și cum să mă fi încumetat? Textul care apare astăzi este exact acela încredințat revistei cu şase luni în urmă” (My translation).

3 “(...) dacă rezistența expresivă, prin operă, a scriitorilor nu a cunoscut decât foarte rar acutele, Cenzura a evitat, la rândul ei, pe cât posibil, intervențiile radicale și măsurile de forță. Interdicțiile totale de publicare a unui manuscris au aparţinut regimului expresiei. În mod curent, atitudinea s-ar zice conciliantă a Cenzurii a fost explicată prin teama de scandal a Puterii, dar și printr-o corectă intuiție a cenzorilor, care se fereau să creeze, precum altădată Inchiziția martiri, figuri exemplare, prin notorietatea conferită" (My translation).

4 “«Centrul» n-a permis, așa cum nu permitea el multe. Situația era stupefiantă: așadar, despre o carte tipărită şi difuzată în 1989 nu este voie să se scrie?! Publicarea ei era, deci, un act propagandistic de «bunăvoință», pentru «calmarea spiritelor», ori mai știu eu ce scopuri obscure" (My translation). 
Ioan Holban's review of Ana Blandiana's anthology was also censored, with the sole explanation of a "definite No," as shown by a Note of the editorial staff in the first issue of the magazine Cronica after the revolution:

\section{EDITORIAL NOTE}

This literary review was written and submitted to our editorial office just after the publication of the great, vertical and brave writer's book, but the odious censorship department of the Council of Culture denied its printing; at least three entreaties from the editorial staff have been met with an answer as if atomic weapons were discussed: a "Definite No," please excuse the quotes. Now, we are doing justice to it and, thus, establish the normality of it 5 (Holban 4$)$.

Publishing previously banned reviews of Ana Blandiana volume Poezii shortly after the 1989 revolution was meant to be an act of re-establishing order and impartiality in a formerly abusive and abused literary history. Nonetheless, the author's name had not been completely banned from the media as articles of synthesis written by Laurentiu Ulici (Ulici, "Sentimentul" 11; Ulici, "Recitind" 11; Ulici, "Critica" 11) and Ion Bălu (Bălu 6-7) mention her all throughout the year 1989 in România Literară. I doubt that it was a case of weakened censorship control. On the contrary, this nonintervention stems from a pre-emptive fear of provoking a backlash from writers had they attempted to alter the literary canon of the 1960's too drastically. On the other end of the spectrum, banning reviews on a singular collection of poems would have a far less legitimizing effect for the author. Moreover, by acknowledging Blandiana as part of the sixties canon, the institution of censorship covers its own mechanisms in a cloak of invisibility.

Allowing the publishing of a literary work, yet censoring the discourses around that same work is an atypical case of censorship. But Blandiana was not alone. Liviu Malița discusses the similar case of Mircea Eliade, whose name was censored in the Săptămâna review, albeit his books were selling in the bookstores (Malița, Cenzura 352-4). It cannot be explained as partial censorship, since its consequences are far greater than those of complete censorship: granting Blandiana the release of her poems subversively aims to discredit her in the eyes of the public. The moment her

5 “Această cronică literară a fost scrisă și predată redacției noastre imediat după apariția cărții marii, integrei și curajoasei scriitoare, dar odioasa cenzură de la Consiliul Culturii a refuzat tipărirea; la cel puțin trei apeluri din partea redacției, răspunsul a fost ca pentru armele atomice: un «Nu hotărât», iertat fie-ne citatul. Dreptatea pe care o facem acum așază lucrurile în normalitate" (My translation). 
book was published in 1989, she lost her status of "banned author" and "opponent to the system," which gave the Power the opportunity to speculate that her absence from publications in previous years had been a personal choice of the writer herself. This becomes more evident judging by the fact that the volume was an anthology of poetry rather than a new literary piece. From the perspective of the Censorship, the anthology must have seemed benign and a way to reaffirm the legitimacy of the regime as it included previously published poems and did not reconfigure the writer's artistic profile. Further proof of the duplicity of their actions lies in the refusal to publish Arhitectura valurilor - eventually printed after the 1989 Revolution - which Blandiana had submitted for assessment as early as 1987. Ana Blandiana was an undesirable author whose transformative subversive discourse is turned away, while her previous work, already accepted and previously validated by the Censorship in the first edition of the poetry volumes now published in the collection of Poezii, is released in spite of the author's status in the eyes of the communist power.

Another aspect which testifies to the extent and manner in which the writer was censored from mid-1988 to December 1989 is the status of her books in public libraries. Her own testimonies are only partially verified: her volume Întâmplări de pe strada mea was indeed withdrawn from public sale, just as the December 1984 issue of Amfiteatru was designated to the Special Collection in public libraries, however, her work from 1988 and her name cannot be found on the list of banned writers in the documents which we have analysed (Caravia, Costea).

Admittedly, the research documents may be incomplete, nevertheless, the absence of her name and her book titles from the official documents of the Censorship throughout 1988 and 1989 might merely be one of their strategies to "divide the institutional entourage" around the poet: her presence in the library catalogues (with the exception of Intâmplări... and the issue from Amfiteatru) would not only attest to the fact that she was not banned, but also discredit her own legitimizing discourse as a writer who had been suffering the interference of censorship.

On the other hand, in spite of having been deprived of her column in România literară and not benefitting from individual reviews, the Romanian poetess succeeded in bypassing the vigilant Censorship and saving herself through her writing, more specifically through her column "Corespondențe" in the literary magazine Familia. She signs the articles in "Corespondențe" until August 1988, while 
after that date her column is replaced by "Poșta redacției" (Familia, Sept. 1988 14), signed by an anonymous writer, a so-called Correspondent. In the September issue, the new column simply publishes the verses of promising writers, yet, as of October, the selected poems are accompanied by commentaries and replies which bear a striking similarity to the writing of the author of Eu scriu, tu scrii, el/ea scrie (Blandiana, "Eu scriu"):

Poetry is not an enumeration of illogical sentences, but string of words which follow their own logic. (...) Objectivity is nothing more than subjectivity ignoring itself out of cowardice $^{6}$ (Corespondent, Oct. 1988 14).

The difference between one poet and another is far less significant than the difference between a poet and a writer of verses ${ }^{7}$ (Corespondent, Nov. 1988 14).

I will not tire of saying that a noble theme does not compensate for the worthless pieces of art that flourishes around it. (...) What your neat, blunt writing lacks in order to become true poetry is animal warmth, hot blood bursting from the poet's nib, dripping between the letter, just as the dry shapes from the herbarium lack their sap to become plants. We all possess talent, but talent is simply a means by which some transport diamonds, others coal, and many more transport synthetic materials. (...) The eloquence of poetry cannot be measured in words but rather in the silence between them ${ }^{8}$ (Corespondent, Jan. 1989 14).

Poetry in fixed forms scare me because of their talent to often hide in beautiful garments the nothingness, because of their perfidy to create masterly buttoned

6 "Poezia nu e o înșiruire de cuvinte lipsite de logică, ci o înșiruire de cuvinte ce se supun unei alte logici, care este numai a ei. (...) [O]biectivitatea nici nu este decẩt o subiectivitate care se ignoră cel mai adesea din lașitate" (My translation).

7 "Ceea ce-l deosebește pe un poet de altul a fost întotdeauna mai puțin important decât ceea ce-l deosebește pe un poet de un autor de versuri” (My translation).

8 "N-o să obosesc niciodată repetând că noblețea nici unei teme nu poate salva sau scuza arta fără valoare care îi crește în jur. (...) Scrisului dumneavoastră îngrijit și lapidar îi lipsește, pentru a deveni poezie, căldura animală, sângele fierbinte năvălind din peniță, picurând dintre litere, așa cum unor forme oricât de frumos ordonate în ierbar le lipseşte, pentru a fi plante, seva. (...) Toți avem talent, dar talentul nu este decât un mijloc de tracțiune cu care unii transportă diamant, alţii cărbune și atât de mulți, materiale sintetice. (...) Elocvența poeziei nu se măsoară prin cuvinte, ci prin liniștea dintre ele" (My translation). 
uniforms which hide, with equal chances, both the poetry and the nothingness 9 (Corespondent, Nov. 1989 14).

From the sharp irony of aphorisms to recurring lexical formulas typical to Blandiana, such as "masterly buttoned," from the rejection of fixed forms to the criticism of talent, or discriminating between "poets" and "verse writers," all these clues reveal the true identity of the Correspondent in the person of the previous author of the column. The miraculous presence of this anonymous column published uninterruptedly for fourteen months in the magazine is the result of an act of solidarity with the oppressed writer among the editorial staff, while the negligence of the (post)censorship is a mystery. The question remains: who assumed the identity of the Correspondent - as it is clear such a negotiation did take place, more so because the previous editor had been cast aside on political grounds. Moreover, what could explain the negligence of the post-censorship control, if there was any? Was it so superficial that it missed all the revealing lexical traces leading to the overlap between the former author of the column and its current author, the anonymous Correspondent? Not to mention the paratextual denominator found in the name - the Correspondent - and the previous editorial "Corespondențe" column signed by Ana Blandiana.

Either the clues were widely disseminated throughout the issues and the reviews Blandiana wrote to aspiring poets were left untraceable to the blind eye of the censors, or the identity of the Correspondent was outright denied by the editor in chief Alexandru Andrițoiu, a respectable figure in the era.

Nonetheless, in the December 1989 issue, the Correspondent finally reveals her identity: "Your Correspondent who is and has always been ANA BLANDIANA" (Familia Dec. 1989 14). In the subsequent issue, in January 1990, the author releases an article bearing a candid and touching title, - "Thank you!" - in which she reflects upon the underlying implications of publishing in spite of the censorship under the fragile veil of anonymity:

I must confess that the idea of writing for Familia still moves me as deeply now when in the whirlwind of life my only concern is finding the time to write -, as it did in

9 "Formele fixe mă sperie prin priceperea lor de a îmbrăca, adesea, prin frumoase veșminte nimicul, prin perfidia de a crea uniforme încopciate savant în care să se poată ascunde, cu șanse egale, poezia sau nimicul” (My translation). 
the past one year and a half when - beginning with my fear of not letting my gender slip through the phrases to the difficulty of having the text reach the paper safely without tracing its origin to me - everything was a concern. At the time I was writing those usual replies in "Poșta redacției" with an overwhelming fervor streaming from the fact that it was the singular means of expression I could afford, like secret messages hidden in bottles on the sea. I cannot go back to the sombre reality of publishing and to the ordinary of psychology before I can thank Dumitru Chirilă and the entire Familia editorial staff - as pathetic as these days can be - for choosing to keep me part of the staff and, thus, never failing to be by my side. The unique gesture of this editorial team - in spite of the jeopardy it implied and due to the courage it required - encouraged me far beyond what anyone can imagine and gave me the justification to hope that the seed of solidary - once believed to have been shattered on Romania soil - was sprouting here and possibly elsewhere as well10 (Blandiana, Jan. 1990 3).

We are left with two major considerations regarding the possibility of writing anonymously: on the one hand, for a writer whose professional status has been denied - as we know, writing has been professionalized in Romania as early as the 1950's (Macrea-Toma 287) - writing under a pen name was a form of therapy, as it offers the chance to preserve a sense of self-diminished as it may be throughout the lines of "Poșta redacției"; on the other hand, the marginal gesture - unique in the era - of the editorial staff to stand in solidarity with the writer deeply roots cultural resistance in the existential realm. The major risks taken by the entire Familia staff by sheltering a persona non grata among their own ought to be acknowledged as such and included in literary history as a pure form of cultural resistance ${ }^{11}$.

10 "Trebuie să mărturisesc că ideea de a scrie pentru revista Familia mă emoționează și acum când, în vârtejul în care trăiesc, singura problemă a rămas aceea de a găsi răgazul să scriu -, ca şi de-a lungul ultimului an și jumătate, când - de la grija de a nu scăpa în formularea frazelor vreo formă de feminin, care m-ar fi putut deconspira, și până la modalitatea de a face textul să ajungă la redacție, fără a se afla că vine de la mine - totul era problemă. Scriam atunci acele atât de curente răspunsuri la «Poșta redacției» cu emoția exagerată a unicei posibilități de exprimare, cu sentimentul că scriu mesaje ascunse în sticle aruncate în mare; nu pot să revin la normalitatea sobră a publicisticii şi a psihologiei înainte de a mulțumi lui Dumitru Chirilă și revistei Familia, cu tot patetismul pe care aceste zile exaltante nu se sfiesc să-l cuprindă, pentru felul în care nu au ezitat să mă păstreze alături de ei și, astfel, să-mi fie alături. Gestul singular al redacției Familia - cu tot curajul și riscul pe care le-a presupus - m-a încurajat mai mult decât îşi poate cineva imagina acum şi mi-a dat dreptul să sper că sămânța solidarității, care părea să fie definitiv spulberată pe sol românesc, există totuși și germinează în adânc, dacă aici, atunci poate și în alte neștiute locuri” (My translation).

${ }^{11}$ On the internet site of the magazine, Ana Blandiana is mentioned among the editors of the column "Poșta redacţiei", but there is no mention regarding her anonymous period. It is regrettable, as the literary magazine should be the first to archive their noble gesture. See Ion Simuţ, "Familia", available at http://revistafamilia.ro/150-de-ani/, accessed 15.03.2019. 
The debate around "cultural resistance" during communism focuses on the relation between the writers and the communist power: on the one hand, there are researchers who consider that "resistance through culture," in fact, is impossible, since literature itself is a product of Censorship (Ficeac 11). Other researchers insist on the atypical character of literature during communism and state that cultural resistance is an anti-political discourse precisely because it avoids the communist ideology, in a mandatorily ideologized culture (Cordoș 20).

Another aspect regarding the cultural resistance is the tendency to either fetishize it, or to ridicule it (Macrea-Toma 337). Adrian Marino draws attention on the tendency to mythicize the resistance through culture, but he also describes it as an unquantifiable state of mind defined by: a free critical spirit, the use of an independent critical language, promoting Western literary values, tackling marginal themes in literature, eluding the prescriptions of censorship (Marino 29-33). Therefore, cultural resistance is perceived as an apolitical attitude, albeit an implicit anti-political one. Moreover, researchers agree that an openly dissident phenomenon was unlikely to coagulate in the Romanian space, due to the lack of solidarity between Romanian writers and the lack of interest the Western democracies had for the communist Romania (Malița, Literatura 343, Verdery 311, Macrea-Toma 287). Liviu Malița defines this resistance through culture as an un-concessive collaboration (Malița, Literatura 340-1), Ioana Macrea-Toma suggests the term diffidence - a state of refrain, of shyness caused by a lack of self-confidence (Macrea-Toma 233). The common denominator for cultural resistance is its non-aggressive character, its half-spoken truth.

Under these circumstances, the texts Ana Blandiana continued to publish anonymously fit in the category of resistance through culture, given their hidden paternity, but they cannot be considered dissident. The solidarity of the staff from Familia with Ana Blandiana, remarkable for that time, also fits in the category of resistance through culture, because its eluding the rule of not publishing a banned author. However, the lack of an open, public opposition does not qualify the gesture as dissident, but as a case of collective diffidence. Even if the texts betray their real author at the level of the discursive tracks, their subversive potential was not sensed by the Censorship or by the Security agents, which places the texts in the same category of cultural resistance. 
Unfortunately, a number of factors made it difficult for Romanian writers to publicly display their discontentment with the communist regime, and Ioana MacreaToma offers a comprehensive inventory: the imperative of professional confirmation, the scarcity of the external relational resources, the lack of a tradition of civic sociability, the laxity and aggressiveness of Censorship, the divergence between the anti-establishment ethos and the temporal visibility, a charismatic circular projection derived from the dawn of the cultural and institutional modernization (Macrea-Toma 337). The only reasonable form of survival, of self-preservation for the Romanian writers was that of cultural resistance, a way of defending the truth of literature from the explicit compromise with the lies of the communist propaganda.

\section{References:}

Bălănică, Vladimir. "Mircea Dinescu, Ana Blandiana, Octavian Paler.” Tomis, Jan. 1990: 8.

Bălu, Ion. "45 de ani de literatură." România literară, 23 Aug. 1989: 6-7.

Blandiana, Ana. "Cruciada copiilor." România literară, 28 Dec. 1989: 23.

---. Eu scriu, tu scrii, el/ea scrie. Cartea Românească, 1976.

---. Familia, Jan. 1990: 3.

---. Familia, Dec. 1989: 14.

Caravia, Paul (ed.). Gândirea interzisă. Scrieri cenzurate. România 1945-1989. Editura Enciclopedică, 2000.

Cordoș, Sanda. În lumea nouă. Dacia, 2003.

Corespondent. Familia, Jan 1989: 14.

---. Familia, Oct. 1988: 14.

---. Familia, Nov. 1988: 14.

---. Familia, Nov. 1989: 14.

Costea, Ionuț, István Király and Doru Radosav. Fond Secret. Fond $S$ „Special”. Contribuţii la istoria fondurilor secrete de bibliotecă din România. Studiu de caz. Biblioteca Central Universitară „Lucian Blaga”, Cluj-Napoca. Dacia, 1995.

Ficeac, Bogdan. Cenzura comunistă şi formarea „omului nou.” Nemira, 1999.

Foucault, Michel. A supraveghea şi a pedepsi. Translated by Bogdan Ghiu, 2nd ed., Paralela 45, 2005.

Holban, Ioan. "O lume de cuvinte." Cronica, 29 Dec. 1989: 4. 
Macrea-Toma, Ioana. Privilighenția. Instituții literare în comunismul românesc. Casa Cărţii de Știință, 2009.

Malița, Liviu. Cenzura pe îț̦elesul cenzuraților. Tracus Arte, 2016.

---. Literatura eretică. Texte cenzurate politic între 1949 și 1977. Cartea Românească, 2016.

Manolescu, Nicolae. "Un sfert de veac de poezie." România literară, 28 Dec. 1989: 9.

---. "Poșta redacției." Familia, Sept. 1988:14.

Marino, Adrian. Politică şi cultură. Pentru o nouă cultură română. Polirom, 1996.

Simuț, Ion. “«Familia» - 150 de ani." Revista Familia, no. 5, 2015, revistafamilia.ro/150-de-ani/. Accesed 15 March 2019.

---. Literaturile române postbelice. Școala Ardeleană, 2016.

Ulici, Laurențiu. "Critica şi editurile.” România literară, 8 Jun. 1989: 11.

---. "Recitind revistele." România literară, 18 May 1989: 11.

---. "Sentimentul de generație." România literară, 4 May 1989: 11.

Verdery, Katherine. Compromis și rezistență: cultura română sub Ceaușescu. Humanitas, 1994. 